\title{
CRLF1 Gene
}

National Cancer Institute

\section{Source}

National Cancer Institute. CRLF1 Gene. NCI Thesaurus. Code C104950.

This gene may be involved in regulating the immune system. 